The Economic Journal of Nepal, Vol. 40, No. 1, 2, 3 \& 4, Jan-Dec 2017 (Issue N0. 148) @ CEDECON-TU

\title{
Foreign Aid in Nepal: Importance, Trends, and Government Initiatives
}

\author{
Dr. Sukanta Sarkar ${ }^{1}$
}

'Foreign aid is as much about knowledge as it is about money. Helping countries and communities generate knowledge that they need for development is the prime role of assistance.' World Bank, 1998

\begin{abstract}
Economic growth and development are in the forefront of international relations and policy making. Developed countries such as the United States and international organizations such as the World Bank and the International Monetary Fund provide assistance that attempts to help the economic growth of developing countries. Foreign aid has been recognized as the most crucial factor in enhancing economic development in many countries. Foreign aid is crucial factor to achieve higher and sustainable economic growth and development of Nepal. However, aid must be linked with sustainable growth and poverty reduction. The objectives of the paper are to study the importance, trends and government initiatives of foreign aids in Nepal.
\end{abstract}

\section{INTRODUCTION}

Nepal is a developing country situated between China and India geographically. It remained almost in isolation from outside world both economically and politically until the fall of more than one century long autocratic regime in 1951. Nepalese economy has been witnessing a gradual change along with the change in political system, from fully agrarian economy to a semi-modern system. Nepal is still one of the poor countries in the world. As in other many developing countries, Nepal began to implement structural adjustment program of IMF and World Bank since the mid-1980s (Shrestha, 2010). Nepal is highly vulnerable to natural disasters and climate change which can push population back into poverty, destroy infrastructure and undermine growth.

Nepal started to liberalize its trade and investment regime, unilaterally, in 1992 and became the first least developed country to join the WTO through the full accession process in April 2004. Since then, economic performance has not resulted in the strong development Nepal needs. Nepal is taking further steps to create a friendlier business environment and environment and help its exporters to become more competitive. Nepal has seen a significant reduction in poverty over the period 1995-2010 which encompasses the decade-long Maoistled civil war (Mitra \& Mitra, 2017).

1 Dr. Sarkar is an Associate Professor at Department of Economics, Gambella University, Ethiopia. Email: SUKANTAECO@GMAIL.COM 
After the rebuilding of majority rule government, the constitution of the Kingdom of Nepal was proclaimed in 1990 that ensures a multiparty approach, an established government, individuals' power and major human rights. The constitution perceives the essentialness of decentralization, the fair dispersion of monetary assets, the rights and welfare of youngsters and the upliftment of monetarily and socially denied groups (Thapa, 2014). The years between 1950 and 1990 were crucial milestones, both in the political history as well as in the history of aid relationships in Nepal. After Nepal joined the United Nations in 1955 and the Colombo Plan in 1956, multilateral agencies started to provide assistance to Nepal, in the form of grants and loans. India and the United States were followed by the United Kingdom, Switzerland, and China, and later by Norway and Japan during the 1960s. Denmark followed in the 1970s and Finland in the 1980 (Bonino \& Donini, 2009). The objectives of the paper are to study the importance, trends and government initiatives of foreign aids in Nepal.

\section{What is Foreign Aids?}

'Foreign Aid' in broadest sense means financial or technical help given by one country's government to another country to assist social and economic development or to respond to a disaster in the receiving country. It can involve providing financial grants or loans, technical advice, training, equipment and commodities such as food, health, infrastructure and transport. Military assistance was considered a form of foreign aid until the 1950 s. Since then, while some countries still provide military assistance and equipment to other countries, it is usually termed foreign military assistance.

Foreign aid is defined as the "voluntary transfer of public resources" from one country to another "to better the human condition in the country receiving the aid". It is measured by the net flow of resources which may or may not facilitate growth. There are two measurements of aid used in foreign aid research: effective development assistance and official development assistance.

- Effective development assistance is the sum of grants and the grant equivalents of official loans whereas official development assistance includes both the direct grants and concessional loans for which the grant component is above 25 per cent". It combines aid in the form of direct grants and the portion of loans that are grants adjusted for inflation to reflect the real cost of providing the aid.

- Official development assistance comprises direct grants and loans that have a grant component greater than 25 percent (Dimanche, 2010).

\section{Importance of Foreign Aid}

Foreign aid is regarded as a key source to bridge the gap between government income and expenditure in Nepal. As the mobilization of internal sources alone may not be sufficient to cover the cost of infrastructures, the needed investment in them could be arranged by the means of foreign aid. The article 59 (6) of the Constitution mandates the Government of Nepal to mobilize foreign resources in the national priorities. The Constitutional so has clear provisions on the role of different tiers of government in foreign aid mobilization.

Foreign aid is the main source of deficit financing in LDCs in the world. Least developed countries have less capacity to mobilize their resources due to low level of income of the people living in these nations. In the past, major sources of development expenditure used to be foreign aid which currently occupies nearly 20 percent of the national budget. The share 
of foreign grant and debt is likely to grow in upcoming years due to the essential for postearthquake reconstruction and rehabilitation works as well as to finance the federal set up (Acharya, 2017).

It is generally argued that most foreign aid tries to achieve one or more of four broad economic and development objectives (Radelet, 2006):

- to stimulate economic growth through building infrastructure, supporting productive sectors or bringing new ideas and technologies,

- to strengthen important sectors, such as, education, health, environment or political systems,

- to support subsistence consumption of food and other essential commodities, especially during relief operations or humanitarian crises, or

- to help stabilize an economy following economic shocks.

Aid has a positive relationship with growth on average across countries (although not in every country), but with diminishing returns as the volume of aid increases. There are three main channels through which aid promotes growth:

- Aid augments savings, finances investment, and adds to the capital stock (Sachs et al, 2004).

- Aid increases worker productivity through investments in health and education.

- Aid promotes the transfer of technology or knowledge from donor to the recipient countries (Chowdhury \& Garonna, 2007).

The recent Paris Declaration on Aid Effectiveness and Accra Agenda for Action have laid out a series of core principles which form a code of good practices to be followed by both donors and aid recipient countries. These principles (e.g. increasing recipient's ownership or aligning aid with the recipient country's priorities) reflect the continuous search for institutional and technical refinement, a focus that has prevailed in the aid sector as the best pathway to improve aid effectiveness (Dhungana \& Sugden, 2014).

\section{Trends of Foreign Aid in Nepal}

In the past 50-odd years, since Nepal received its first foreign aid from the United States via the Marshall Plan, 'the total contribution of foreign aid to the national expenditure has amounted to [Nepal rupees, NPR] 268 billion', including an NPR 159 billion loan and NPR 109 billion grant. Foreign aid accounts for 27 percent in total national expenditure and exceeds 50 percent in development expenditure. The grants have helped spread education, constructed roads and bridges, established industries, and, over the last decade, reduced the percentage of people living below the poverty line from 42 percent to 31 percent. In the 1960s and 1970s, Nepal received more aid from bilateral assistance than from multilateral donors and the 'share of grants used to be around three-fourths of total aid'.

The end of 'Cold War' brought changes in aid policy; donors began to express their concerns about human rights situations in recipient countries. The restoration of democracy in Nepal in 1990 coincided with the third wave of democracy. EU countries, like other donors, have a distinct image as development partners of Nepal. The international community has been tempted to involve itself more on soft projects like democracy building and empowering marginalized groups than costly hardware economic developments (such as 
building roads and bridges and harnessing hydroelectricity) for several reasons (Hachhethu, 2009).

Foreign aid has been the subject of a great deal of development rhetoric in Nepal. Although its objectives have rarely been met, foreign aid continues to shape Nepal's development's priorities, modalities and outcomes. Currently, around 70 percent of the country's development expenditure is financed by external aid and this has remained more or less constant for the last four decades (Pandey, 2011).

Table 1: Trends of Foreign Aid in Nepal

(Rs. in million)

\begin{tabular}{|c|c|c|c|}
\hline Fiscal years & Grants & Loans & Total Foreign Aid \\
\hline $1950 / 51$ & 1.01 & - & 1.01 \\
\hline $1951 / 52$ & 1.01 & - & 1.01 \\
\hline $1955 / 56$ & 1.01 & - & 1.01 \\
\hline $1956 / 57$ & 1 & - & 1 \\
\hline $1962 / 63$ & 128.36 & & 128.36 \\
\hline $1963 / 64$ & 125 & 13.44 & 138.44 \\
\hline $1970 / 71$ & 270.69 & 32.46 & 303.14 \\
\hline $1980 / 81$ & 993.3 & 729.9 & 1723.2 \\
\hline $1990 / 91$ & 1630 & 4360 & 5990.0 \\
\hline $2000 / 01$ & 6753.4 & 12044 & 18797.4 \\
\hline $2005 / 06$ & 19574.8 & 6162.70 & 2537.5 \\
\hline $2007 / 08$ & 20320.72 & 8979.87 & 29300.59 \\
\hline $2008 / 09$ & 26328.86 & 99688.61 & 36297.74 \\
\hline $2009 / 10$ & 38545.97 & 11223.38 & 49769.35 \\
\hline $2010 / 11$ & 45922.17 & 12075.60 & 57997.77 \\
\hline $2011 / 12$ & 40810.28 & 11083.07 & 51893.35 \\
\hline $2012 / 13$ & 35229.80 & 11969.44 & 47199.24 \\
\hline $2013 / 14$ & 42205.7 & 17998.82 & 60204.52 \\
\hline
\end{tabular}

Source: Various Issue of Economic Survey from 1950/51 to 2013/14, Ministry of Finance (MOF), Government of Nepal (GON).

The table shows the share of loan and grant in foreign aid in the process of economic development of Nepal. Up to 1970, foreign aid flow to Nepal confined to diminutive size. During the period 1950-70, bilateral grant played a predominant role in the structure of foreign aid in Nepal. During 1980s and 90s assistance was rapidly increased which was provided by the multilateral financial institutions like ADB, IDA and other UN agencies. However, the composition of aid changed significantly when she asked to borrow. In 2000/01, Nepal received 64.07 percent in the form of loan and 35.93 percent in the form of grants. Again, the situation has been changed in 2009/10, grants shares was 77.4 percent, while loans was 22.6 percent (Pandey, 2017). The contribution of foreign aid in the development of Nepal is shown in Table 2. 
Table 2: The Contribution of Foreign Aid in Periodic Development Plans of Nepal

(Rs. in million)

\begin{tabular}{|c|c|c|}
\hline Plan Period & Development Expenditure & Foreign Aid \\
\hline 1st plan & 389.2 & 389.2 \\
\hline 2nd plan & 617.7 & 478.5 \\
\hline 3rd plan & $1,639.1$ & 919.8 \\
\hline 4th plan & $3,356.9$ & $1,509.1$ \\
\hline 5th plan & $8,870.6$ & $4,264.1$ \\
\hline 6th plan & 21,750 & 13,260 \\
\hline 7th plan & $48,345.4$ & $23,978.5$ \\
\hline 8th plan & $111,918.8$ & 49,203 \\
\hline 9th plan & $2,151,454.4$ & $9,131.25$ \\
\hline 10th plan & $16,200.25$ & $36,139.1$ \\
\hline 11th plan & $65,524.5$ & $9,354.88$ \\
\hline 12th plan & $17,584.28$ & . \\
\hline
\end{tabular}

Sources: Various Periodic Plans, National Planning Commission (NPC) \& Various Issue of Economic Survey, MOF, GON

Table 2 shows the role of foreign aid in periodical plans of Nepal. The developmental expenditure in each periodic plan was heavily financed by foreign aid which shows the role of foreign aid is supplement and enhance Nepal's meagre domestic saving so as to mobilize increasing resources for poverty alleviation (Pandey, 2017).

Trends of aids since April 2006 have not been positive. The majority of donors have resumed programmes (halted after the royal coup) and/or made increased commitments, without proper assessment of the changing context needs. This trend is reflected in the UNDP and National Planning Commission's MDG Needs Assessment for Nepal. Instead, the report states that there is a financing gap of US\$7.9 billion for reaching the MDGs by 2015 and recommends almost doubling the present level of financial support by Nepal's external development partners. This recommendation is based on the assumption of 'a relatively quick resolution to the current conflict in the country'.

Japan has assisted Nepal to accelerate the country's democratization and peace building. Grant Aid started with food aid in 1970 and mainly focused on the basic social sectors of health/medical services, education, as well as development of basic infrastructure in the transport and power sectors. Japanese loan aid was provided mainly for projects.

China's first assistance was to support Nepal's Five Year Plan. China's importance has declined considerably and its share in total bilateral aid stood at about four per cent by the late 1980s. The Chinese aid-financed projects are mainly in transport and industry. However, China also provides aid to other sectors such as hydropower and irrigation, public facilities, health, education and sports. China has constructed many important highways, such as the Prithivi highway, which links Kathmandu and Pokhara, Nepal's only tourist centre, apart from Kathmandu. As a result, this highway opened up significant economic opportunity for ordinary

People, in addition, China helped build the ring road around Kathmandu, the trolley bus system, and the Kathmandu to Bhaktapur road. China also provided financial assistance to establish a number of industries - industries that had great significance during the period when Nepal pursued import substitution policies. 
Nepal became a member of the World Bank on $6^{\text {th }}$ September 1961. While the Bank's office was opened in 1971 in Kathmandu, its operations began in 1969. Its first credit was provided to a telecommunications project from the International Development Association. The World Bank has been providing funds for the development of infrastructure, telecommunications, education, Structural Adjustment Programs, and poverty reduction programs and projects. Since 1970, the bank has funded six road projects in Nepal and the building of suspension bridges in various parts of the country. These projects have generated economic opportunities in some of Nepal's poorest regions. They improved the quality of transportation between Kathmandu and the rest of the country, as well as strengthening the maintenance capabilities of the road department.

The World Bank has been involved in the development of telecommunications in Nepal since November 1969. A more modern and reliable long-distance network has been established, helping to bring telecommunication services to rural areas. The World Bank has also provided finance for education projects. These have developed the educational sector in many respects, their major achievements being institutional development, staff training, building construction, the introduction of computers and equipment's, curriculum and textbook development, and the introduction of new education programs. In the 1980s, the World Bank supported the implementation of the Structural Adjustment Program. Recently, the World Bank has begun to focus more on supporting Nepal's Poverty Reduction Strategy Paper. World Bank has been supporting infrastructure projects that help promote demanddriven irrigation schemes managed by local water user groups, and water supply schemes, which reduce the time women spend collecting water.

Nepal became a member of the IMF on $30^{\text {th }}$ September 1961. The Structural Adjustment Facility (SAF) and Stand-By Arrangement (SBA) were implemented during the 1980s in conjunction with the World Bank's Structural Adjustment Programs. Nepal was one of the 31 founding members of the ADB, which was established in 1966. The ADB lends to Nepal on highly concessional terms of interest (1.5 percent per annum, with loan repayments typically due over 32 years with 8-year grace periods), from its soft-lending window, the Asian Development Fund. The first loan of US\$ 6 million was for air transport development, in 1969. Since then, ADB loans have been increasing to Nepal. In the social infrastructure sector, the ADB financed projects in primary and secondary education, rural water supply and sanitation, gender and development, and urban management (Bhattarai, 2005).

\section{Development Assistance of India}

Government of India provides development assistance to Nepal, focusing on creation of infrastructure at the grass-root level, under which various projects have been implemented in the areas of infrastructure, health, water resources, education and rural \& community development. In recent years, India has been supporting projects in Nepal for development of infrastructure through up gradation of roads in the Terai areas; development of cross-border rail links at Jogbani-Biratnagar, Jaynagar Bardibas, Nepalgunj Road-Nepalgunj, NautanwaBhairhawa, and New Jalpaigudi Kakarbhitta; and establishment of Integrated Check Posts at Raxaul-Birgunj, Sunauli-Bhairhawa, Jogbani-Biratnagar, and Nepalgunj Road-Nepalgunj. More than 551 large, intermediate and small-scale projects at an estimated cost of NRs. 76 Billion have been implemented across Nepal under Indian financial support since 1951. The total economic assistance earmarked under 'Aid to Nepal' budget for FY 2017-18 amounts to Rs. 375 crores. 
In the early days, Indian assistance was given more for infrastructure projects, such as roads, railways and airports. During the FY 2017-18, a total of around 18 intermediate and large projects are under various stages of implementation in Nepal. These include creation of a Nepal Bharat Maitri Dharamshala at Pashupati area at Kathmandu; construction of a Polytechnic at Hetauda, providing Indian faculty support to BP Koirala Institute of Health Sciences at Dharan, Installation of 2700 shallow tube wells in various districts across Nepal etc. Till date, India has gifted 602 ambulances and 118 school buses to various institutions and health posts across Nepal's 75 districts. 17 fire tenders were gifted to the Ministry of Federal Affairs and Local Development in August, 2016, for enhancing fire-fighting capacity of municipal administration in different parts of Nepal. Besides this, Government of India supported the Election Commission of Nepal in May 2017 with vehicles and other logistical materials for smooth conduct of local elections in Nepal.

Apart from grant assistance, Government of India has also extended four lines of credit to the Government of Nepal for US\$ 100 million, US\$ 250 million, US\$ 550 million and US\$ 750 million for execution of infrastructure development projects and post-earthquake reconstruction projects as prioritized by GON. The Indian Aid Mission (IAM) was established in Nepal in the year 1954, which was later merged with the Indian Embassy in Kathmandu, Nepal. The initial focus was on infrastructural projects, which involved building roads, bridges, hydropower systems and airports to name a few.

Since 1950s, owing to both cultural and geographical relations between the two countries, India has emerged as one of the most prominent bilateral donors for Nepal. According to the Development Cooperation Report 2015-16, India ranks fifth amongst the top five bilateral developing partners of Nepal for the financial year 2015-16, with USD35 million in official development assistance disbursements.25 India's rank improved in the year 2016-17. India has emerged as the fourth largest bilateral donor to Nepal in the fiscal year 2016-17.26 The total economic assistance earmarked under the Aid to Nepal budget for the financial year 2016-17 amounts to INR3000 million (US\$ 47 million approximately) and for the year 2017-18, it is INR 3750 million (US\$ 58.67 million approximately) (Goyal, 2018).

\section{Government Initiatives}

In Nepal, debt management is the responsibility of the Ministry of Finance (MoF) and Nepal Rastra Bank (NRB). A Debt Management Unit (DMU) under the Foreign Aid Coordination Division of the MoF is responsible for recording loan details and monitoring payments. The Financial Comptroller General's Office (FCGO) records actual disbursements and authorizes payment on loans. External funds are received and foreign payments are made through NRB which records and monitors private sector loans and domestic debt instruments (Alamgir \& Ra, 2005).

Loans and Guarantee Act, 1958 first ratified to regulate and direct the foreign loan and offering guarantee on any form of loan received from multilateral and bilateral agencies. Than after a Foreign Aid Policy-2002, a written government's policy paper was endorsed to harmonize the foreign aid in Nepal. As per the Loans and Guarantee Act, 1968, the GoN has been increasing the amount of ceiling set on the inflow of foreign loans under the unitary system. In the federal structure, the federal government is required to borrow foreign loans in different forms (bilateral or multilateral; concessional or other forms of loan) to bridge the resource gap in all tiers of government. As such, this act shall set certain criteria on the mobilization on external loan assistance under the federal set-up. 
The Foreign Aid Policy, 2002 AD was replaced by Development Cooperation Policy, $2014 \mathrm{AD}$. The very move was gravitated towards readjusting the fundamentals of the country's foreign aid sector in sync with the shifting values of the aid philosophy in the global scenario. The political system and structure is drastically overhauled with the implementation of the Constitution in Nepal.

The 'Foreign Aid Management' is responsible and has authority for the coordination and mobilization of bilateral and multilateral development cooperation. The ministry is responsible for not only processing and assessing all the project documents but also responsible for coordinating in every phase of project cycle including project preparation, appraisal, negotiation and agreement, among others.

Nepal has been a recipient of foreign aid since joining the Colombo Plan for Cooperative, Economic, and Social Development in Asia and the Pacific in 1952. Aid makes up a substantive part of Nepal's annual government budget. In fiscal year 2016/2017 approximately 29 percent of the annual budget expenditure was aid-supported in the form of grants (10 percent) and loans (19 percent). According to the MoF's Red Book of budget details this proportion has grown in recent years, with 25 percent of the annual government budget expenditure supported by foreign aid in FY 2015/167, and 20 percent in FY 2014/15.8 The volume of foreign aid disbursed in FY 2016/17 was US\$ 1,581.14 million. Of this, US\$ 186.54 million (12 percent) was from INGOs and US\$1,394.6 million (88 percent) was Official Development Assistance (ODA). Of the total ODA disbursement US\$ 830.27 million (60 percent) was provided by multilateral DPs, while US\$ 564.33 million (40 percent) came from bilateral DPs (Pradhan \& Zellmann, 2018).

\section{Conclusion}

Foreign aid is regarded as a key source to bridge the gap between government income and expenditure in Nepal. Although its objectives have rarely been met, foreign aid continues to shape Nepal's development's priorities, modalities and outcomes. Currently, around 70 percent of the country's development expenditure is financed by external aid and this has remained more or less constant for the last four decades. Aid makes up a substantive part of Nepal's annual government budget. In sum, all indicators show that foreign aid has played a major role in Nepal, and it remains a highly aid-dependent country. Aid is not bad and must be effectively utilized to attain national objective.

\section{References}

Acharya, K. (2017). Foreign aid in Nepal, pp. 1-6.

Alamgir, M., \& Ra, S. (2005). Nepal public debt sustainability analysis. NRM Working Paper No. 5, p.1-4.

Bhattarai, B. (2005), The effectiveness of foreign aid: A case study of Nepal, pp. 1-67.

Bonino, G. \& Donini, D. (2009). Aid and violence: Development policies and conflict in Nepal, pp. 1-6.

Chowdhury, A. \& Garonna, P. (2007). Effective foreign aid, economic integration and subsidiarity: lessons from Europe, No. 2, pp. 1-10.

Dhungana, H. \& Sugden, F. (2014), Social and environmental justice in foreign aid: A case study of irrigation interventions in western Nepal, Nepal journal of social science and public policy, 3 (1), pp. 65-75. 
52 I The Economic Journal of Nepal (Issue No. 148)

Dimanche, K. (2010), Foreign aid and economic growth, pp. 1-12.

Goyal, T. (2018). India's development assistance to Nepal: Case of the education sector, pp. $1-12$.

Hachhethu, K. (2009), The European Union's role in democracy building in Nepal, pp. 1-15.

Mitra, A. \& Mitra, S. (2017). Redistribution of economic resources due to conflict: The Maoist uprising in Nepal, p.1.

Pandey, D. (2011). Looking at development and donors: Essays from Nepal, p.192.

Pandey, K. (2017). Foreign aid in Nepal. Economic Journal of Development Issues, Vol. 23 \& 24 No. 1-2, pp. 71-75.

Pradhan, K. \& Zellmann, C. (2018). Aid data needs and use cases in Nepal, pp. 1-19.

Radelet, S. (2003), Challenging foreign aid: A policymaker's guidetot the millennium challenge account, Washington: Center for Global Development. pp. 1-5.

Shrestha, B. (2012). Contribution of foreign employment and remittances to Nepalese economy, pp. 4-7.

Shrestha, P. (2010). Structural changes and economic growth in Nepal, pp. 1-5.

Thapa, N. (2014). Foreign aid and its impact on governance in Nepal, MPRA Paper No. 58960, posted 29, pp. 1-8. 